\title{
Human health risk assessment of heavy metals in road dust collected in Cracow
}

\author{
Gabriela Hajduga $^{1, *}$, Agnieszka Generowicz ${ }^{1}$, and Małgorzata Kryłów ${ }^{1}$ \\ ${ }^{1}$ Cracow University of Technology, Department of Environmental Engineering, Department of \\ Environmental Technologies, ul. Warszawska 24, 31-155 Cracow, Poland
}

\begin{abstract}
Road dust is viewed as one of the major contributors for metal pollution in urban environment and long-term exposure can cause chronic damage through ways of inhalation, ingestion, and dermal contact so they pose a great threat on human health. The article presents a study conducted to determine the concentrations of seven heavy metals in road dust from a chosen street in Cracow, and the impact of heavy metals contamination in surface street dust on human health using Health Risk Assessment. The health risk was assessed using Hazard Quotient (HQ), Health Index (HI) and Carcinogenic Risk (RI).
\end{abstract}

\section{Introduction}

Dust on urban impervious surface which also contain heavy metals, has become one of the most important issues in urban environmental management and it's considered as toxic [1-3]. It can be easily re-suspended under certain outside dynamic condition, pollutants adsorbed on them enter human body by the pathways of respiratory inhalation and direct skin contact $[1,4,5]$. Pollutants attached to surface dust can be also transferred to the surrounding aquatic environment with runoff.

In the face of the harmful effects of heavy metals, more attention is devoted to issues of health risk assessment, which relies on qualitative and quantitative characteristics of the probability of negative health effects as a result of exposure to a given factor. As different types of chemicals bring different influences on human bodies, risk assessments of these chemicals can be characterized by non-carcinogenic risk (HI) and carcinogenic risk (RI), Carcinogenic risk refers to the incremental probability of an individual developing any kind of cancer as a result of exposure to carcinogens [7, 8].

The purpose of this work is to assess the health exposure of the inhabitants of Halszki Street in Krakow, resulting from the presence of heavy metals such as cadmium, nickel copper, lead zinc, chromium and manganese in the street dust of one of the streets [9-12]. In addition, the results were referred to the results of the Life Cycle Assessment (LCA) carried out on a similar subject and compared with result of Health Risk Assessment carried out for another major street in Kraków [11, 12].

\footnotetext{
${ }^{*}$ Corresponding author: gabriela.hajduga@gmail.com
} 


\section{Materials and methods}

The basis for this research were the results of the qualitative composition collected material as a result of sweeping processes and washing up of streets - waste and sewage. Street sweeping activities were carried out in cooperation with the following entities: Miejskie Przedsiębiorstwo Oczyszczania in Cracow Sp. z o.o. (Municipal Cleaning Company), Provincial Inspectorate for Environmental Protection and the Faculty of Environmental Engineering of the Cracow University of Technology.

The results of the composition of collected and washed waste comes from Halszki Street in Cracow. The segment on which the research was carried out was about $1.1 \mathrm{~km} \mathrm{long}$. This street has been qualified for roads with traffic exceeding 1000 cars per hour. Halszki Street is the main access road to the nearest housing estates with a variable width of 9 to $10 \mathrm{~m}$. There are no parking spaces or green lanes along the route. On both sides of the road, along its entire length, there is a footpath for pedestrians with a width of about $2 \mathrm{~m}$. The street, is mainly surrounded by residential blocks and urban greenery at sports facilities.

The sampling were collected within 7 consecutive days of the week in the month of April. To avoid impediments related to car traffic, samplings were carried out at night, starting from 23:00. First, the street was swept along both street sides and across its entire width. After this stage, each day samples of solid waste material were collected from the sweeper tank for the needs of laboratory tests. Each day they were collected to $500 \mathrm{ml}$ polyethylene containers as in similar studies carried out by [4]. Next, using a water tanker, the street section was washed, and at selected points (at the beginning of the route, in the middle and at the end), samples of sewage were collected, which were also subjected to separate laboratory analysis for the purposes of Life Cycle Assessment.

Laboratory tests were carried out at the Provincial Inspectorate for Environmental Protection in Cracow. The samples were tested for the concentration of such elements as Zinc, Manganese, Copper, Nickel, Lead, Cadmium and Total Chrome. The concentrations of heavy metals were determined according to the following standards: PN-EN 13657:2006, PN-ISO 8288:2002, PN-EN 1233:2000 p. 3. The first one determined the method of extraction of soluble pearl substitutes from waste by solution with royal water. From samples taken each day, 3 samples were prepared, which were further prepared for analysis. This included drying and reduction of grain size below $250 \mu \mathrm{m}$ particle size, and docking after drying, the material was sieved through a $1 \mathrm{~mm}$ mesh sieve and the fraction $<63 \mu \mathrm{m}$ was separated as potentially posing the greatest threat to health). The weight of a single sample prepared according to the recommendations always exceeded $20 \mathrm{mg}$ and amounted to $0.50 \mathrm{~g}$ (weighed to the nearest $0.0001 \mathrm{~g}$ ), then $6 \mathrm{ml}$ of $\mathrm{HCl}$ and $2 \mathrm{ml}$ of $\mathrm{HNO}_{3}$ were added separately and the dilution procedure according to the program 1) $2 \mathrm{~min}, 250 \mathrm{~W}$;2) $2 \mathrm{~min}$, $0 \mathrm{~W}$; 3$) 5 \mathrm{~min}, 250 \mathrm{~W}$; 4) $5 \mathrm{~min} 400 \mathrm{~W}$; 5 ) $5 \mathrm{~min}, 500 \mathrm{~W}$, was started. Then the contents of vessels were quantitatively transferred to the measuring flask, supplemented to the mark and then the analysis was performed. Concentrations of heavy metals were determined by atomic absorption spectrometry with flame atomization (PN-ISO 8288:2002, PN-EN 1233:2000 p.3.). The accuracy of the method was evaluated using the standard addition method. Table 1 presents average concentrations of heavy metals in solid waste.

Table 1. Average concentrations of heavy metals in collected solid waste.

\begin{tabular}{|c|c|c|c|c|c|}
\hline Chemical element & Unit & Result & Chemical element & Unit & Result \\
\hline Cadmium & $\mathrm{mg} / \mathrm{kg}$ & 5.13 & Zinc & $\mathrm{mg} / \mathrm{kg}$ & 333.73 \\
\hline Nickel & $\mathrm{mg} / \mathrm{kg}$ & 24.93 & Chrome & $\mathrm{mg} / \mathrm{kg}$ & 122.17 \\
\hline Copper & $\mathrm{mg} / \mathrm{kg}$ & 171.33 & Manganese & $\mathrm{mg} / \mathrm{kg}$ & 788.97 \\
\hline Lead & $\mathrm{mg} / \mathrm{kg}$ & 46.77 & & & \\
\hline
\end{tabular}




\subsection{Health risk assessment}

In this study, the model that was used to assess health risk of Halszki Street residents was derived from a model advanced by the United States Environmental Protection Agency and it was widely used by other authors in the literature [4, 14-18]. It was assumed that heavy metals penetrate the body in an unintentional manner through oral, inhalation and dermal routes (exposure paths) $[1,4,5,7,9,11]$. Another assumption proposed by EPA was the duration of life, during which residents would be exposed to heavy metals. In the case of adults, it EPA assumes that it would be 70 years, and in the case of children -6 years $[8,9$, 11]. Environmental exposure was estimated on the basis of the average dose, which determines the amount of harmful substance taken by the studied population per day and per $1 \mathrm{~kg}$ of body weight. Dose values for each route of exposure have been calculated from equation from 1 to $3[9,12-14]$.

$$
\begin{gathered}
D_{\text {ing }}=\frac{c \cdot R_{i n g} \cdot C F \cdot E F \cdot E D}{B W \cdot A T} \\
D_{\text {inh }}=\frac{c \cdot R_{\text {inh }} \cdot E F \cdot E D}{P E F \cdot B W \cdot A T} \\
D_{\text {derm }}=\frac{c \cdot S A \cdot C F \cdot S L \cdot A B S \cdot E F \cdot E D}{B W \cdot A T}
\end{gathered}
$$

For carcinogens, the Lifetime Average Daily Dose (LADD) (inhalation exposure route for nickel, and cadmium; inhalation, ingestion exposure route for chromium) was utilized in the evaluation of cancer risk then calculated using equation (4) [7, 11, 12, 14-18]. The meanings and values of the parameters are listed in Table 2.

$$
L A D D=\frac{c \cdot E F}{P E F \cdot A T} \cdot\left(\frac{C R_{\text {child }} E D_{\text {child }}}{B W_{\text {child }}}+\frac{C R_{\text {adult }} \cdot E D_{\text {adult }}}{B W_{\text {adult }}}\right)
$$

Table 2. Parameters and their values $[1,4,5,9,11,12,14-18]$.

\begin{tabular}{|c|c|c|c|c|}
\hline \multirow{2}{*}{ Factor } & Definition & \multirow{2}{*}{ Unit } & \multicolumn{2}{|c|}{ Value } \\
\cline { 4 - 5 } & concentration of the contaminant in dusts & $\mathrm{mg} / \mathrm{kg}$ & \multicolumn{2}{|c|}{ Table 1} \\
\hline $\mathrm{c}$ & ingestion rate & $\mathrm{mg} / \mathrm{day}$ & 200 & 100 \\
\hline $\mathrm{R}_{\text {ing }}$ & inhalation rate & $\mathrm{m} / \mathrm{day}$ & 7.6 & 20 \\
\hline $\mathrm{R}_{\text {inh }}$ & exposure frequency & days $/ \mathrm{year}$ & \multicolumn{2}{|c|}{330} \\
\hline $\mathrm{EF}$ & exposure duration & years & 6 & 70 \\
\hline $\mathrm{ED}$ & average body weight & $\mathrm{kg}$ & 15 & 70 \\
\hline $\mathrm{BW}$ & average time & days & \multicolumn{2}{|c|}{$365 \cdot \mathrm{ED}$} \\
\hline $\mathrm{AT}$ & conversion factor & $\mathrm{kg} / \mathrm{mg}$ & \multicolumn{2}{|c|}{$1 \cdot 10^{-6}$} \\
\hline $\mathrm{CF}$ & particle emission factor & $\mathrm{m}^{3} / \mathrm{kg}$ & \multicolumn{2}{|c|}{$1 \cdot 10^{9}$} \\
\hline PEF & surface area of the skin that contacts the dust & $\mathrm{cm}^{2}$ & 2800 & 5700 \\
\hline SA & skin adherence factor for dust & $\mathrm{mg} / \mathrm{cm}^{2}$ & 0,2 & 0,7 \\
\hline SL & dermal absorption factor & - & \multicolumn{2}{|c|}{0.001} \\
\hline ABS & & & \multicolumn{2}{|c|}{} \\
\hline
\end{tabular}

Health risk, which is a function of human exposure to toxic substances, was assessed using the Hazard Quotient (HQ) which was calculated according to equation 5 [9].

$$
H Q=\frac{D}{R f D}
$$

$D$-absorbed dose $\left[\frac{\mathrm{mg}}{\mathrm{kg} \cdot \mathrm{d}}\right] ; R f D$-reference dose $\left[\frac{\mathrm{mg}}{\mathrm{kg} \cdot \mathrm{d}}\right]$. 
The reference dose (RfD) is an estimation of maximum permissible risk on human population through daily exposure during a lifetime. The threshold of RfD value can be used to indicate whether there would be an adverse health effect during a life time. If an average daily dose (D) value is lower than the reference dose, there would not be any adverse health effect; otherwise it is likely that the exposure pathway will cause adverse human health effect $[1,4,5,9,11,12,14-18,19]$ (table 3 ).

The HQs can be added to generate Hazard Index (HI) (equation 6) which allows to estimate the risk of mixed heavy metal contaminates. HI presents total risk of non-carcinogenic metals and if the value of $\mathrm{HI} \leq 1$ there is no significant risk, but if $\mathrm{HI}>1$, there is a great chance of non-carcinogenic effects to human health $[1,4,5,9,11,12,14-18$, 20-23]. The same rule applies to individual HQ values.

Table 3. Reference doses for heavy metals in accordance do exposure pathways [11].

\begin{tabular}{|c|c|c|c|c|}
\hline \multirow{2}{*}{ Chemical element } & \multirow{2}{*}{ Unit } & \multicolumn{3}{|c|}{ RfD } \\
\hline & & $\mathrm{RfD}_{\text {ing }}$ & $\mathrm{RfD}_{\text {inh }}$ & $\mathrm{RfD}_{\text {derm }}$ \\
\hline Cadmium & \multirow{7}{*}{$\mathrm{mg} / \mathrm{kg} \cdot \mathrm{d}$} & $1.00 \mathrm{E}-03$ & $1.00 \mathrm{E}-03$ & $1.00 \mathrm{E}-03$ \\
\hline Nickel & & $2.00 \mathrm{E}-02$ & $2.06 \mathrm{E}-02$ & $5.40 \mathrm{E}-03$ \\
\hline Copper & & $4.00 \mathrm{E}-02$ & $4.02 \mathrm{E}-02$ & $1.02 \mathrm{E}-02$ \\
\hline Lead & & $3.50 \mathrm{E}-03$ & $3.52 \mathrm{E}-03$ & $5.25 \mathrm{E}-04$ \\
\hline Zinc & & $3.00 \mathrm{E}-01$ & $6.00 \mathrm{E}-02$ & $3.00 \mathrm{E}-01$ \\
\hline Chrome & & $3.00 \mathrm{E}-03$ & $2.86 \mathrm{E}-05$ & $6.00 \mathrm{E}-05$ \\
\hline Manganese & & $1.40 \mathrm{E}-01$ & $5.00 \mathrm{E}-05$ & $5.60 \mathrm{E}-03$ \\
\hline
\end{tabular}

$$
H I=H Q_{C d}+H Q_{C u}+H Q_{P b}+H Q_{Z n}+H Q_{M n}+H Q_{N i}+H Q_{C r}
$$

It is also possible to calculate the total exposure to the considered heavy metals for each exposure path (7).

$$
H I=H Q_{i n g}+H Q_{\text {derm }}+H Q_{i n h}
$$

For carcinogens the index of RI is used and it can be calculated by the following equations:

$$
\begin{gathered}
R I=L A D D \cdot S F \\
R=R I_{\text {ing }}+R I_{\text {derm }}+R I_{\text {inh }}
\end{gathered}
$$

The slope factor (SF) converts estimated daily intake averaged over a lifetime of exposure directly to incremental risk of an individual. The cancer risk is sum of carcinogenic risk of individual carcinogens in the possible exposure pathways $(\mathrm{R})[9,11,16,18,21]$. According to the U.S. EPA, the value of cancer risk in the range of $10^{-6}$ to $10^{-4}$ is an acceptable or tolerable risk, a risk of less than $10^{-6}$ can be ignored, and a risk exceeding $10^{-4}$ is considered to unacceptable. In calculations for carcinogenic exposure, the US EPA guidelines do not make calculations in the distinction between adults and children [1, 9, 11, 22, 23].

\section{Results}

\subsection{Comparison with Aleje Krasińskiego}

On the exact same date, samples was also taken from Aleje Krasińskiego located in the city center. This route characterizes with heavy traffics over 3000 vehicles per hour which is 3 times more than on Halszki Street. Along of this road we have old tenements, commercial 
buildings and public buildings which use gas or electrical heating. For samples taken from that site, it was also possible to calculate Health Risk for citizens from that area. Result for both location are presented in tables from 4 to 7 . During the time of sampling the nearest air quality measurement station to Halszki Street registered max. concentration of PM10 - 80 $\mu \mathrm{m} / \mathrm{m} 3$, min. $34 \mu \mathrm{m} / \mathrm{m} 3$ (three days when, the concentration was below the alarm level -50 $\mu \mathrm{m} / \mathrm{m} 3$ ), whereas on Krasińskiego max. concentration of PM10 - $160 \mu \mathrm{m} / \mathrm{m} 3$, min. 39 $\mu \mathrm{m} / \mathrm{m} 3$ (only during one day, the concentration was below the alarm level).

Table 4. Comparison of the Health Risk Assessment results for Halszki Street and Aleje Krasińskiego.

\begin{tabular}{|c|c|c|c|c|c|c|c|c|}
\cline { 2 - 10 } \multicolumn{1}{c|}{} & \multicolumn{4}{c|}{ Adults Halszi Street } & \multicolumn{4}{c|}{ Adults Al. Krasínskiego } \\
\hline $\begin{array}{c}\text { Chemical } \\
\text { element }\end{array}$ & HQ $_{\text {ing }}$ & HQ $_{\text {inhal }}$ & $\mathbf{H Q}_{\text {derm }}$ & HI $_{\text {adults }}$ & HQ $_{\text {ing }}$ & HQ $_{\text {inhal }}$ & HQ $_{\text {derm }}$ & HI $_{\text {adults }}$ \\
\hline Cadmium & $6.63 \mathrm{E}-03$ & $9.74 \mathrm{E}-07$ & $2.64 \mathrm{E}-04$ & $7.70 \mathrm{E}-03$ & $7.40 \mathrm{E}-03$ & $1.09 \mathrm{E}-06$ & $2.95 \mathrm{E}-04$ & $6.89 \mathrm{E}-03$ \\
\hline Nickel & $1.61 \mathrm{E}-03$ & $2.30 \mathrm{E}-07$ & $2.37 \mathrm{E}-04$ & $2.18 \mathrm{E}-03$ & $1.90 \mathrm{E}-03$ & $2.70 \mathrm{E}-07$ & $2.80 \mathrm{E}-04$ & $1.85 \mathrm{E}-03$ \\
\hline Copper & $5.53 \mathrm{E}-03$ & $8.08 \mathrm{E}-07$ & $8.66 \mathrm{E}-04$ & $8.48 \mathrm{E}-03$ & $7.33 \mathrm{E}-03$ & $1.07 \mathrm{E}-06$ & $1.15 \mathrm{E}-03$ & $6.40 \mathrm{E}-03$ \\
\hline Lead & $1.73 \mathrm{E}-02$ & $2.52 \mathrm{E}-06$ & $4.59 \mathrm{E}-03$ & $3.94 \mathrm{E}-02$ & $3.11 \mathrm{E}-02$ & $4.55 \mathrm{E}-06$ & $8.25 \mathrm{E}-03$ & $2.19 \mathrm{E}-02$ \\
\hline Zinc & $1.44 \mathrm{E}-03$ & $1.06 \mathrm{E}-06$ & $5.73 \mathrm{E}-05$ & $2.05 \mathrm{E}-03$ & $1.97 \mathrm{E}-03$ & $1.45 \mathrm{E}-06$ & $7.87 \mathrm{E}-05$ & $1.50 \mathrm{E}-03$ \\
\hline Chrome & $5.27 \mathrm{E}-02$ & $8.11 \mathrm{E}-04$ & $1.05 \mathrm{E}-01$ & $1.69 \mathrm{E}-01$ & $5.60 \mathrm{E}-02$ & $8.64 \mathrm{E}-04$ & $1.12 \mathrm{E}-01$ & $1.59 \mathrm{E}-01$ \\
\hline Manganese & $7.29 \mathrm{E}-03$ & $3.00 \mathrm{E}-03$ & $7.27 \mathrm{E}-03$ & $2.22 \mathrm{E}-02$ & $9.21 \mathrm{E}-03$ & $3.80 \mathrm{E}-03$ & $9.20 \mathrm{E}-03$ & $1.76 \mathrm{E}-02$ \\
\hline
\end{tabular}

Table 5. The Results of Health Risk Assessment results for Aleje Krasińskiego.

\begin{tabular}{|c|c|c|c|c|c|}
\hline \multicolumn{7}{|c|}{ Cancer Risk Al. Krasińskiego } \\
\hline $\begin{array}{c}\text { Chemical } \\
\text { element }\end{array}$ & SF $_{\text {inh }}$ & LADD $_{\text {inh }}$ & SFing $_{\text {ing }}$ & LADDing & $\begin{array}{c}\text { Cancer } \\
\text { risk (R) }\end{array}$ \\
\hline Cadmium & 6.3 & $1.3 \mathrm{E}-09$ & & & $8.19 \mathrm{E}-09$ \\
\hline Nickel & 0.84 & $6.4 \mathrm{E}-09$ & & & $5.38 \mathrm{E}-09$ \\
\hline Chrome & 42 & $2.9 \mathrm{E}-08$ & 0.5 & $2.20 \mathrm{E}-07$ & $1.33 \mathrm{E}-06$ \\
\hline
\end{tabular}

Table 6. The Results of Health Risk Assessment results for Halszki Street.

\begin{tabular}{|c|c|c|c|c|c|}
\hline \multicolumn{7}{|c|}{ Cancer Risk Halszki Street } \\
\hline $\begin{array}{c}\text { Chemical } \\
\text { element }\end{array}$ & SF $_{\text {inh }}$ & LADD $_{\text {inh }}$ & SF $_{\text {ing }}$ & LADDing $_{\text {ing }}$ & $\begin{array}{c}\text { Cancer } \\
\text { risk (R) }\end{array}$ \\
\hline Cadmium & 6.30 & $1.1 \mathrm{E}-09$ & & & $6.93 \mathrm{E}-09$ \\
\hline Nickel & 0.84 & $5.5 \mathrm{E}-09$ & & & $4.62 \mathrm{E}-09$ \\
\hline Chrome & 42.00 & $2.7 \mathrm{E}-08$ & $5.0 \mathrm{E}-01$ & $2.1 \mathrm{E}-07$ & $1.24 \mathrm{E}-06$ \\
\hline
\end{tabular}


Table 7. Comparison of the Health Risk Assessment results for Halszki Street and Aleje Krasińskiego.

\begin{tabular}{|c|c|c|c|c|c|c|c|c|}
\hline & \multicolumn{4}{|c|}{ Children ul. Halszki } & \multicolumn{4}{|c|}{ Children Al. Krasińskiego } \\
\hline $\begin{array}{c}\text { Chemical } \\
\text { element }\end{array}$ & HQ ing & HQinhal & $H_{\text {derm }}$ & HIchildren & HQing & HQinhal & $H_{\text {derm }}$ & HIchildren \\
\hline Cadmium & $6.18 \mathrm{E}-02$ & $1.73 \mathrm{E}-06$ & $1.73 \mathrm{E}-04$ & $6.20 \mathrm{E}-02$ & $6.91 \mathrm{E}-02$ & $1.93 \mathrm{E}-06$ & $1.93 \mathrm{E}-04$ & $6.93 \mathrm{E}-02$ \\
\hline Nickel & $1.51 \mathrm{E}-02$ & $4.08 \mathrm{E}-07$ & $1.56 \mathrm{E}-04$ & $1.53 \mathrm{E}-02$ & $1.77 \mathrm{E}-02$ & 4.80E-07 & $1.84 \mathrm{E}-04$ & $1.79 \mathrm{E}-02$ \\
\hline Copper & $5.18 \mathrm{E}-02$ & $1.44 \mathrm{E}-06$ & 5.67E-04 & $5.24 \mathrm{E}-02$ & $6.85 \mathrm{E}-02$ & $1.90 \mathrm{E}-06$ & $7.52 \mathrm{E}-04$ & $6.93 \mathrm{E}-02$ \\
\hline Lead & $1.61 \mathrm{E}-01$ & 4.49E-06 & $3.01 \mathrm{E}-03$ & $1.64 \mathrm{E}-01$ & $2.89 \mathrm{E}-01$ & 8.04E-06 & $5.41 \mathrm{E}-03$ & 2.94E-01 \\
\hline Zinc & $1.34 \mathrm{E}-02$ & $1.87 \mathrm{E}-06$ & 3.77E-05 & $1.34 \mathrm{E}-02$ & $1.84 \mathrm{E}-02$ & $2.57 \mathrm{E}-06$ & 5.17E-05 & $1.85 \mathrm{E}-02$ \\
\hline Chrome & $4.90 \mathrm{E}-01$ & $1.44 \mathrm{E}-03$ & $6.87 \mathrm{E}-02$ & $5.60 \mathrm{E}-01$ & $5.23 \mathrm{E}-01$ & $1.53 \mathrm{E}-03$ & 7.33E-02 & $5.98 \mathrm{E}-01$ \\
\hline Manganese & $6.79 \mathrm{E}-02$ & $5.32 \mathrm{E}-03$ & $4.75 \mathrm{E}-03$ & $7.80 \mathrm{E}-02$ & $8.64 \mathrm{E}-02$ & $6.74 \mathrm{E}-03$ & $6.02 \mathrm{E}-03$ & $9.92 \mathrm{E}-02$ \\
\hline
\end{tabular}

\subsection{Comparison with LCA}

Life cycle assessment according to the official definition given by the European Commission is the process of collecting and evaluating the input and output data of the product as well as assessing the potential impact on the environment throughout its life cycle (production, use and utilization). In used LCA model, there were two categories of influence relating to humans. One is "Toxic effect on humans - carcinogenic effect" and the other "Toxic effect for humans - action other than carcinogenic". The unit for these categories of human impact is the Comparative Toxic Unit for Humans (CTUh) and expresses the estimated increase in mortality in the total human population, i.e. the number of cases per $1 \mathrm{~kg}$ of emitted substance (Table 8). In case of Halszki Street, LCA analysis was carried out on the basis of developed various emission variants, assuming different distribution of pollutant emissions contained in street dust to the environment. The most unfavorable in terms of impact on humans turned out to be a variant where $70 \%$ of pollutants are emissions to air, another $15 \%$ goes to water and $15 \%$ to soil. For adopted allocation of emission, the Health Risk Assessment was carried out, with the assumption that $70 \%$ of the emission goes to air and puts people at risk through accidental ingestion, dermal contact and inhalation (variant 1 ); $15 \%$ of emission goes to water and puts people at risk only through ingestion (variant 2); $15 \%$ of the emission goes to the soil and puts people at risk through ingestion and dermal contact (variant 3 ), then the results were referred to the results of the LCA analysis.

Table 8. The results of the LCA analysis in relation to categories concerning human health.

\begin{tabular}{|l|c|c|}
\hline \multicolumn{1}{|c|}{ Category of influence } & Unit & Value \\
\hline Toxic effect for humans - action other than carcinogenic & CTUh & 0.0052 \\
\hline Toxic effect on humans - carcinogenic effect & CTUh & 0.0004 \\
\hline
\end{tabular}

Due to the change in concentrations, the risk values decreased accordingly. There were no changes in the range of elements from the least to the most toxic.

\section{Disscusion and conclusions}

Although these areas are different from each other, in many respects mentioned above, the analysis indicates that zinc and chromium are the greatest threats to the health of adults. More interestingly, the results show an almost twofold risk pattern for lead closely related to car 
traffic. For none of the above cases, the risk does not exceed the limit value. In the case of children, again the smallest health hazard in Halszki Street is characterized by zinc, and the largest chrome. This time the results are not completely transferred to Aleje Krasińskiego, where 'the less risky' of metals turned out to be nickel. Again, the biggest difference is for lead where the risk value increased by $80 \%$. The risk values for chromium for children, compared to adults in both cases are almost 3.5 times higher.

The results obtained for each case confirm the information from the LCA analysis. The risk analysis shows that when it comes to carcinogenic activity, chromium is the most important, and the LCA analysis showed that chromium is in more than $90 \%$ responsible for the result in the Toxic effect on humans category, which gives us 0,0004 cancer cases per $1 \mathrm{~kg}$ emission of a given substance. In turn, in the case of Toxic effect for humans - action other than carcinogenic in $94.8 \%$, for the result of the category, responsible were lead, zinc and chromium. That gives us 0.0052 cases per $1 \mathrm{~kg}$ of emission of a given substance.

In an ideal scenario the analysis would be carried out based on average year load of heavy metals, but at this moment, it's not possible due to the lack of access and the possibility to carry out regular field studies. Because of that, the Health Risk Assessment was calculated for a given composition of street dust, converted into exposures to that composition throughout the year. At this moment, although the method was developed by the U.S. Agency, it can be considered transferable on favourable terms. A handbook with examples for analysis does not say anything to develop it for a particular community or area. It is based on a breakdown into exposure pathways and dose limits that may endanger humans. These have been mainly determined by laboratory tests on animals. In addition, elements such as exposure time, can be assumes. In this case, 330 days were assumed assuming 26 days of leave for the average person and additional 9 special days where an adult with a family can leave the city. The EPA guidelines are also used by authors conducting research in China, Thailand or Pakistan. In Poland, risk is not a popular indicator, but if there was a greater interest in the subject, environmental agencies maybe would undertake to prepare their own guidelines.

As mentioned above, the topic needs to be further developed. In the nearest future, research with different assumptions will start to be carried out with a plan of keeping regularity in sampling and for closed area.

\section{Acknowledgements}

We would like to thank the Management Board and Employees of Cracow MPO Sp. z o.o. for the opportunity to undertake research and analysis.

In a special way we would like to thank the Presidents of MPO Sp. z o.o. Kraków: Henryk Kultys and Andrzej Natkaniec for indicating the area of research and their technical support, Director Jacek Sobczyk for his goodwill, time and professional help

\section{References}

1. X. Liu, Q. Song, Sci. Total. Environ. 1, 463-464 (2013)

2. A. Generowicz, K. Gaska, G. Hajduga, E3S Web. Conf. 44 (2018)

3. G. Hajduga, A. Generowicz, E3S Web. Conf. 17 (2017)

4. X. Han, X. Lu, Int. J. Env. Res. Pub. He. 14, 8, 886-898 (2017)

5. Y. Liang, X. Yi, Int. J. Env. Res. Pub. He. 14, 12, 1557-1574 (2017)

6. K. Gaska, A. J. Wandrasz, Waste. Manage. 28, 6, 973-985 (2007) 
7. L. He, B. Gao, X. Luo, J. Jiao, H. Qin, C. Zhang, Y. Dong, Sustainability-Basel. 10, 4, $1-12$ (2018)

8. G. Sun G, Z. Li, J. Chen, T. Wu, X. Feng, Int. J. Env. Res. Pub. He. 14, 3, 261-272 (2017)

9. M. Trojanowska, R. Świetlik, Bezpieczeństwo i Ekologia 12, 476-477 (2016)

10. A. Mahmood, R. N. Malik, Pakistan. Arab J. Chem. 7, 1, 91-99 (2014)

11. http://www.epa.gov/ncea/efh.

12. J. Ma, W. Singhirunnusorn, Proc. Soc Behv. 50, 1, 280-293 (2012)

13. L. Ferreira-Baptista, E. De Miguel, Atmos. Environ. 39, 4501-4512 (2005)

14. G. Shi, Z. Chen, C. Bi, L. Wang, J. Teng, Y. Li, S. Xu, Atmos. Environ. 45, 764-771 (2011)

15. H. Chen, X. W. Lu, L. Y. Li, T. N. Gao, Y. Y. Chang, Sci. Total Environ. 484, 27-53 (2014)

16. A. A. Jennings, Z. Li, J. Environ. Manag. 160, 16-29 (2015)

17. A. A. Jennings, Z. Li, J. Environ. Manag. 160, 226-240 (2015)

18. M. Alghamdi, M. Khoder, Int. Env. Res. Pub. He. 15, 11, 2397-2417 (2018)

19. J. Mohmand, S. A. Eqani, M. Fasola, A. Alamdar, I. Mustafa, N. Ali, L. Liu, S. Peng, H. Shen, Chemosphere 132, 142-151 (2015)

20. Y. Du, B. Gao, H. Zhou, H. Hao, S. Yin, Procedia. Environ. Sci. 18, 299-309 (2013)

21. C. Zhang, Q. Qiao, E. Appel, B. Huang, J. Geochem. Explor. 119-120, 60-75 (2012)

22. J. A. Acosta, M. Gabarrón, A. Faz, S. Martínez-Martínez, R. Zornoza, J. M. Arocena, Chemosphere 134, 328-337 (2015)

23. G. F. Birch, A. Scollen, Aust. J. Soil. Res. 41, 1329-1342 (2003) 